\title{
In vivo egg recovery from the vaginae and the pattern of egg distribution in superovulated rabbits
}

\author{
Yoshio Tsutsumi, Yutaka Terami, Tetsuo Takeda, \\ Hiroyuki Suzuki and Shigeru Matsui \\ Department of Animal Science, Faculty of Agriculture, \\ Hokkaido University, Sapporo 050, Japan
}

\begin{abstract}
Summary. The oviducts and uteri of superovulated rabbits were cleared to locate the eggs by the freeze-clearing method, and in vivo vaginal washings were prepared to recover the eggs from the vagina during the preimplantation stage. The distribution pattern of eggs in cleared specimens showed that egg transport through the isthmus was faster by about 18 hours as compared with that in normal does. The earliest eggs were recovered from the vagina 42 hours post coitum (p.c.) and most of eggs obtained were recovered concentrically during 2 to 4 days p.c. About $44 \%$ of the superovulated eggs were recovered by multiple vaginal washings up till $192 \mathrm{hr}$ p.c. Four young were obtained in a doe, transferred with the eggs recovered from the vagina of the superovulated does.

A few eggs were recovered from the vagina of naturally mated doe 96 and $120 \mathrm{hr}$ p.c. without pregnant mare serum gonadotropin (PMSG) and human chorionic gonadotropin (hCG). When 20 or $100 \mathrm{IU}$ hCG were given at mating, some eggs were recovered from the vagina 96 or $72 \mathrm{hr} p$.c., respectively. Therefore, the early appearance of many eggs in the vagina of the superovulated doe must be due to priming with PMSG.
\end{abstract}

(Japan. J. Anim. Reprod. 26, 6-14, 1980)

\section{Introduction}

Recovery rates of eggs from the reproductive tract in superovulated rabbits are reported to vary according to the lapse of time after ovulation. The egg recovery rates from the oviduct were reported as 81 to $100 \%$ during 24 to $40 \mathrm{hr} p . c .^{1-4)}$ The recovery rates from the oviduct and uterus at $48 \mathrm{hr} p$. $c$. were reported as $75 \%$ by TAKEUCHI et al., ${ }^{1)} 48$ to $85 \%$ by SAKUMA et al., ${ }^{\mathrm{b})} 23.9$ to $81.4 \%$ by ISHIJIMA and SAKUMA ${ }^{6)}$ and 55.6 to $88.3 \%$ by IsHIJIMA et $a l .{ }^{7)} \quad$ Thus, increasing loss of eggs from the oviduct and/or uterus has suggested that accelerated egg transport through the oviduct occurs in superovulated does..$^{1,3,8-11)}$ It was reported recently that $13 \%$ and $12 \%$ of the eggs in superovulated rabbits were found in the ligated vagina at autopsy 70 and $82 \mathrm{hr}$ p.c. respectively. ${ }^{12)}$ ADAMS $^{13)}$ described that the correct timing of the entry of eggs into the uterus is vitally important for their survival, and that if entry is premature, the eggs are quickly transported through the uterus and are expelled into the vagina.

Eggs can be recovered from the vagina of estrogen-, progesterone- or prostaglandin $\mathrm{F}_{2 \alpha^{-}}$ treated does within 1 to 2 days $p . c$. by a vaginal washing method proposed by TSUTSUMI and TAKEDA $^{14)}$ and some of the eggs recovered from the vagina develop into normal young. ${ }^{15-10)}$ From the experiment which examined the effect of the administration of oxytocin on the egg transport, ${ }^{20)}$ it was speculated that the physical stimulation by the vaginal washings did not alter the egg transport. The observations mentioned above prompted us to apply the vaginal washing method to recover the 
eggs from superovulated does. Because 200 IU PMSG (Serotropin, Teikoku-zōki, Japan), HODGSON and PAUERSTEIN ${ }^{21)}$ postulated that followed by intravenous injection of $100 \mathrm{IU}$ induction of ovulation by hCG and by mating hCG (APL, Ayerst or Primogonyl, schering) respectively had different effects on the propulsion or resistance of the uterotubal junction in egg transport, the effect of hCG administration at mating on the egg recovery from the vagina was examined in the present study, also.

\section{Materials and Methods}

Fifty-two Japanese adult female white rabbits used in Experiments I and II, were superovulated by intramuscular injection of 80 hours later. PMSG treated females were mated twice with bucks at the time of hCG injection (cf. HAFEZ and SUgAwARA ${ }^{22)}$, Fujimoto et al., ${ }^{23)}$ EL-BANNA and SACHER ${ }^{12)}$ ).

In Experiment I, 38 superovulated does were separated into 8 groups consisting of 3 to 6 does, according to the time of autopsy. They were killed at $18,24,36,48,60,72,84$, or 96 $\mathrm{hr}$ p.c. by an overdose of sodium pentobarbital (Somnopentyl) (Tables 1, 2). Vaginae of these does were washed one to eight times before

Table 1. Recovery of eggs from the vagina of superovulated rabbits before killing

\begin{tabular}{|c|c|c|c|c|c|c|c|c|c|c|c|c|}
\hline \multirow{2}{*}{$\begin{array}{l}\text { Time of } \\
\text { sacrifice } \\
\text { (hr p.c.) }\end{array}$} & \multicolumn{10}{|c|}{ No. of eggs recovered at indicated hours after mating } & \multirow{2}{*}{$\begin{array}{l}\text { Total no. } \\
\text { of eggs } \\
\text { recovered }\end{array}$} & \multirow{2}{*}{$\begin{array}{c}\text { Recovery } \\
\text { rate* } \\
(\%)\end{array}$} \\
\hline & 18 & 24 & 36 & 48 & 54 & 60 & 72 & 78 & 84 & 96 & & \\
\hline 18 & 0 & & & & & & & & & & 0 & 0.0 \\
\hline 24 & - & 0 & & & & & & & & & 0 & 0.0 \\
\hline 36 & - & 0 & 0 & & & & & & & & 0 & 0.0 \\
\hline 48 & - & 0 & - & 19 & & & & & & & 19 & 7.4 \\
\hline 60 & - & 0 & - & 52 & 4 & 1 & & & & & 57 & 23.4 \\
\hline 72 & - & 0 & - & 14 & 13 & 2 & 5 & & & & 34 & 16.2 \\
\hline 84 & - & 0 & - & 0 & 0 & 0 & 3 & 17 & 2 & & 22 & 15.5 \\
\hline 96 & - & 0 & - & 0 & 13 & 1 & 18 & 14 & 11 & 9 & 66 & 43.4 \\
\hline Total & 0 & 0 & 0 & 85 & 30 & 4 & 26 & 31 & 13 & 9 & 198 & - \\
\hline
\end{tabular}

* The recovery rate against the number of ovulation points or corpora lutea.

Table 2. Numbers of eggs detected in the reproductive tracts

\begin{tabular}{|c|c|c|c|c|c|c|c|c|c|}
\hline \multirow{2}{*}{$\begin{array}{l}\text { Time of } \\
\text { sacrifice } \\
\text { (hr p.c.) }\end{array}$} & \multirow{2}{*}{$\begin{array}{l}\text { No. of } \\
\text { does }\end{array}$} & \multirow{2}{*}{$\begin{array}{l}\text { No. of } \\
\text { corpora } \\
\text { lutea }\end{array}$} & \multicolumn{6}{|c|}{ No. of eggs detected in } & \multirow{2}{*}{$\begin{array}{c}\text { Detection } \\
\text { rate } \\
(\%)^{* *}\end{array}$} \\
\hline & & & Ampulla & Isthmus & $\begin{array}{c}\text { Uterine } \\
\text { horn }\end{array}$ & Cervix & Vagina* & Total & \\
\hline 18 & 5 & 174 & 86 & 30 & 0 & 0 & 0 & 116 & 68.2 \\
\hline 24 & 5 & 214 & 90 & 91 & 0 & 0 & 0 & 181 & 84.6 \\
\hline 36 & 5 & 344 & 54 & 247 & 0 & 0 & 0 & 301 & 87.5 \\
\hline 48 & 5 & 257 & 1 & 177 & 14 & 0 & 19 & 211 & 82.1 \\
\hline 60 & 5 & 244 & 0 & 114 & 28 & 1 & 57 & 200 & 82.0 \\
\hline 72 & 5 & 210 & 1 & 24 & 127 & 4 & 34 & 190 & 90.5 \\
\hline 84 & 3 & 142 & 0 & 0 & 124 & 6 & 22 & 152 & 107.0 \\
\hline 96 & 4 & 152 & 0 & 6 & 49 & 7 & 66 & 128 & 84.2 \\
\hline
\end{tabular}

* Refer to Table 1.

** Total no. of eggs/no. of corpora lutea. 
killing (see schedule in Table 1). The apparatus and the method for the vaginal washing were the same as those reported previously. ${ }^{18)}$ Immediately after the final vaginal washing, the does were killed to investigate the distribution of eggs in the oviduct and in the uterus. The abdominal wall was opened immediately after killing, most of the digestive tracts were removed quickly, and the whole reproductive organ was frozen in situ by pouring liquid nitrogen into the abdominal cavity, as reported by Howe. ${ }^{24)}$ After thawing, the oviduct and uterus with cervices were excised en bloc, trimmed, and cleared in benzyl benzoate according to the the clearing technique by ORSINI. ${ }^{25)}$ Eggs in the cleared oviduct and uterus were located under a dissecting micro- scope with transmitted light. Ovulation points or corpora lutea of the ovary were counted after removing the reproductive tract.

In Experiment II, 14 superovulated does were separated into 2 groups according to the time of vaginal washings during the preimplantation stage (Table 3). Since vaginal eggs were recovered $48 \mathrm{hr}$ p.c. in Experiment I, the vaginal washings were made at intervals of 6 hours in most cases during 48 to $96 \mathrm{hr}$ p.c. in group I. A few eggs were recovered from the first vaginal washing of this group at $24 \mathrm{hr}$ p.c. Therefore, the frequency of vaginal washing were increased during 24 to $54 \mathrm{hr}$ p.c. in group II. All does were laparotomized 9 days p.c. to record the number of implantation sites and corpora lutea. Some

Table 3. Recovery of eggs from the vagina during the preimplantation stage and numbers of implantation sites in superovulated does

\begin{tabular}{|c|c|c|c|c|}
\hline \multirow{2}{*}{$\begin{array}{c}\text { Time of vaginal } \\
\text { washing (hr p.c.) }\end{array}$} & \multicolumn{4}{|c|}{ Mean no. of eggs recovered per a doe (range) } \\
\hline & \multicolumn{2}{|c|}{ group $I^{\mathrm{a}}$} & \multicolumn{2}{|c|}{ Group $I^{b}$} \\
\hline 24 & 0.5 & $(0-3)$ & 0.0 & $(0)$ \\
\hline 42 & - & & 7.0 & $(0-35)$ \\
\hline 45 & - & & 3.9 & $(0-15)$ \\
\hline 48 & 1.5 & $(0-7)$ & 2.3 & $(0-7)$ \\
\hline 51 & - & & 1.4 & $(0-4)$ \\
\hline 54 & 1.3 & $(0-5)$ & 5.3 & $(0-20)$ \\
\hline 60 & 1.5 & $(0-8)$ & - & \\
\hline 66 & - & & 7.1 & $(0-16)$ \\
\hline 72 & 2.5 & $(0-6)$ & 3.3 & $(0-14)$ \\
\hline 78 & 3.0 & $(0-14)$ & 2.6 & $(0-16)$ \\
\hline 84 & 1.8 & $(0-7)$ & - & \\
\hline 90 & - & & 2.9 & $(0-22)$ \\
\hline 96 & 0.7 & $(0-2)$ & 0.3 & $(0-1)$ \\
\hline 120 & 0.3 & $(0-1)$ & 0.0 & (0) \\
\hline 144 & 0.0 & $(0)$ & 0.0 & (0) \\
\hline 168 & 0.3 & $(0-2)$ & 0.1 & $(0-1)$ \\
\hline 192 & 0.0 & $(0)$ & 0.6 & $(0-2)$ \\
\hline No. of eggs recovered per a doe & 13.5 & $(0-31)$ & 36.6 & $(14-56)$ \\
\hline No. of corpora lutea per a doe & 76.3 & $(32-138)$ & 86.3 & $(64-123)$ \\
\hline Mean recovery rates $(\%)$ & 14.5 & $(0.0-29.5)$ & 44.2 & (15.9-68.8) \\
\hline No. of implantation sites per a doe & 9.5 & $(0-25)$ & 0.25 & $(0-1)$ \\
\hline
\end{tabular}

a: Group I consists of 6 does.

b: Group II consists of 8 does. 
eggs recovered from the vagina were transplanted to the oviducts of a recipient doe to examine the viability of the eggs.

In Experiment III, 32 does were separated into 3 groups according to hCG dosage. Ten does were mated twice and received no hCG (group III). Twelve mated does were given $20 \mathrm{IU} \mathrm{hCH}$ at time of mating (group IV), and 10 mated does were given $100 \mathrm{IU}$ hCG (group V). The vagina of each rabbit was washed once a day for 6 or 7 days, and the numbers of corpora lutea and implantation sites were recorded by laparotomy 9 days p.c. The vaginal washing started from 1 day p.c. in groups III and IV, and from 2 days p.c. in group V.

\section{Results}

\section{Experiment I}

Recovery of vaginal eggs before killing: The numbers of eggs recovered from the vagina at the designated time before killing are shown in Tables 1 and 2. No eggs were recovered until $36 \mathrm{hr}$ p.c. and the first appearance of eggs in the vagina was $48 \mathrm{hr}$ p.c. Sixty-six eggs were recovered from the vaginae of does killed $96 \mathrm{hr}$ p.c. A recovery rate of $43.4 \%$ of eggs ovulated was attained, although the numbers of eggs recovered at each hour after copulation varied.

Distribution of eggs in the oviduct and uterus: The numbers of eggs detected in cleared specimens and recovered from the vagina at various hours after copulation are shown in Table 2. All eggs were found in the ampulla or isthmus of the oviduct until $36 \mathrm{hr}$ p.c. At $48 \mathrm{hr}$ p.c. $6.6 \%$ of the eggs detected were located in the uterine horn and 9.0\% were recovered from the vagina simultaneously. At $72 \mathrm{hr}$ p.c. most of the eggs $(66.8 \%)$ were located in the uterine horn, and at $84 \mathrm{hr}$ p.c. no eggs were found in the oviduct. By $96 \mathrm{hr}$ p.c., however, 52\% of the eggs were recovered from 8 vaginal flushings before killing (Table 1).

Locations of eggs in the oviducts or uteri were expressed by the percentage of distance travelled from the ostium of oviduct or from the uterotubal junction (Fig. 1). The egg distribution pattern in the oviduct showed that $52.6 \%$ of the eggs detected were located in segment 10 of the ampulla $18 \mathrm{hr}$ p.c., although a few eggs advanced near the uterotubal junc-

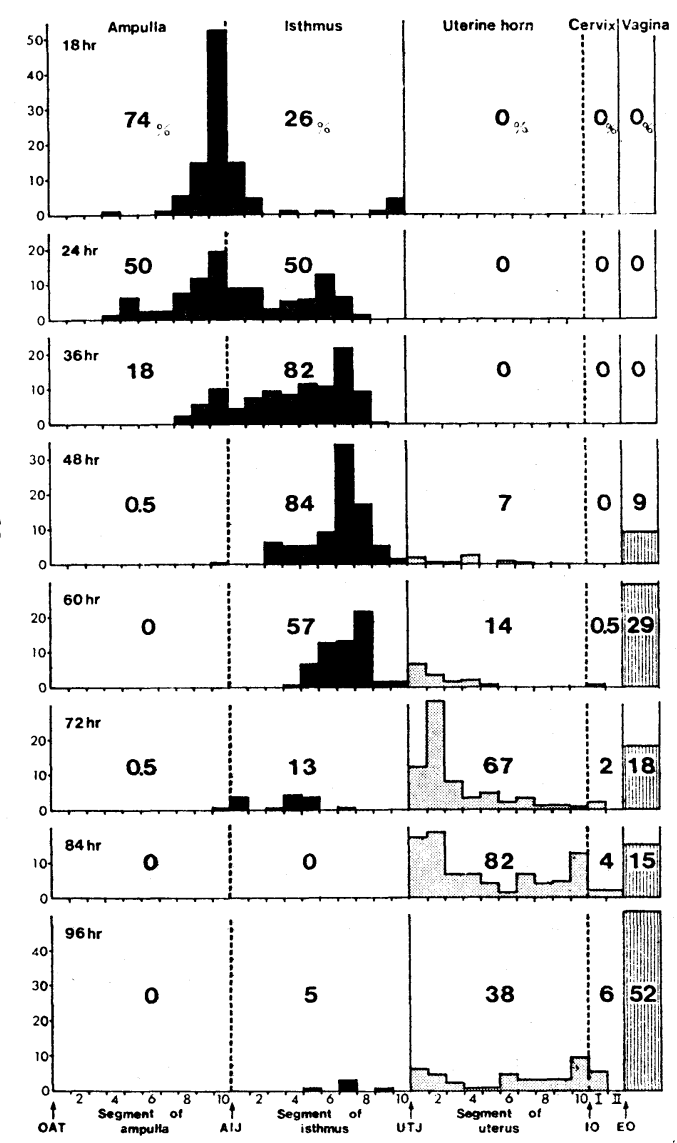

Fig. 1. Changes of distribution of eggs in relation to time in hours post coitum in the reproductive tracts of superovulated does. OAT, ostium abdominal tubae; AIJ, ampullary-isthmic junction; UTJ, uterotubal junction; 10 , internal os; EO, external os. 
tion (UTJ). At $24 \mathrm{hr}$ p.c. a half of the eggs had passed through the ampullary-isthmic junction (AIJ) and at $36 \mathrm{hr}$ p.c. $82.1 \%$ of the eggs were distributed in the isthmus. At 48 to $60 \mathrm{hr}$ p.c. most of the eggs $(83.9 \%$ or $57.0 \%$ ) were in segments 6 to 8 of the isthmus, and the rest were found in the uterine lumen or recovered from the vagina.

In the uterus, $6.6 \%$ and $14.0 \%$ of the eggs were in the distal half of the uterine horn 48 and $60 \mathrm{hr}$ p.c. respectively, although $9.0 \%$ and $28.5 \%$ of the eggs were recovered from the vagina before killing. At 72, 84 and $96 \mathrm{hr}$ p.c. eggs were distributed throughout the uterine horn. However, eggs were concentrated in segments 1 and 2 at 72 and $84 \mathrm{hr}$ p.c. and in segment 10 at 84 and $96 \mathrm{hr}$ p.c.

The numbers of eggs found in the cervix increased gradually from 60 to $96 \mathrm{hr}$ p.c.

\section{Experiment II}

Eighty-one eggs were obtained by vaginal washings in group I, and 293 eggs were recovered by 120 washings in group II. Most of eggs obtained were recovered concentrically during 2 to 4 days p.c. (Table 3). In group I, $86 \%$ of eggs were recovered 48 to $84 \mathrm{hr}$ p.c., and in group II, 97\% of eggs were obtained 42 to $90 \mathrm{hr}$ p.c. The earliest eggs were unexpectedly detected in a doe of group I by the first washing at $24 \mathrm{hr}$ p.c. These were 3 unfertilized and degenerated eggs coated with an extraordinarily thick mucin layer. It was speculated that these eggs had been retained in the oviduct for a long period before recent ovulation. During the period between 96 and $192 \mathrm{hr}$ p.c., a few eggs and several fragments of expanded broken zona pellucida were recovered in both groups. The mean rates of egg recovery were lower in group I $(14.5 \pm 4.4 \%)$ than in group II $(44.2 \pm 6.6 \%)$, although the rates of egg recovery were varied in each doe (range, 0-68.8\%). The difference found in recovery rates may be due to the dfference in times of vaginal washings during the early hours p.c. In group I, 57 implantation sites were counted in 3 does, and 7 young were delivered from 2 does. In group II, on the contrary, only 2 degenerated sites of implantation were recognized in 2 does, and no offspring were obtained. It was clearly seen that the number of implantation sites decreased as the number of eggs expelled into the vagina increased.

Twenty eggs in 2-cell or 8-cell stage, recovered from the vagina $48 \mathrm{hr}$ p.c., were transferred to the oviducts of a synchronized pseudopregnant recipient. At 9 days p.c. laparotomy showed 4 implantation sites, and 4 offspring were obtained on 31 days p.c. These results demonstrate that some of the eggs recovered from the vagina of the superovulated does are viable.

\section{Experiment III}

The effects of hCG administration at mating on the egg recovery from the vagina are summarized in Table 4 . Only 3 of 10 mated does without hCG treatment became pregnant (group III), and 4 eggs were recovered from the vagina in one of the does 96 and $120 \mathrm{hr}$ p.c. When $20 \mathrm{IU}$ hCG was given at mating (group IV), 8 of 12 does became pregnant, the tendency of egg appearance in the vagina was similar to that in group III. When $100 \mathrm{IU}$ hCG was given (group V), 8 eggs were recovered from 4 pregnant does 72 and $96 \mathrm{hr}$ p.c. Three eggs were obtained from 2 nonpregnant does 72 and $120 \mathrm{hr}$ p.c. Although no significant differences were found between the numbers of eggs recovered from the vagina and the numbers of implantation sites among 3 groups, 
Table 4. Effect of hCG injection at mating on number of eggs recovered from the vagina and numbers of corpora lutea and implantanion sites 9 days p.c.

\begin{tabular}{|c|c|c|c|}
\hline Group & III & IV & $\mathrm{V}$ \\
\hline Dose of hCG (IU) & 0 & 20 & 100 \\
\hline No. of does used & 10 & 12 & 10 \\
\hline No. of does ovulated & 3 & 11 & 10 \\
\hline No. of pregnant does (9 days $p . c$. ) & 3 & 8 & 7 \\
\hline Total no. of corpora lutea & 31 & 105 & 114 \\
\hline Total no. of implantation sites & 24 & 46 & 54 \\
\hline Mean no. of implantation sites per a pregnant doe & 8.0 & 5.8 & 7.7 \\
\hline $\begin{array}{l}\text { No. of does recovered eggs from the vagina } \\
\text { No. of eggs recovered from the vagina } \\
\text { indicated hours p.c. }\end{array}$ & 1 & 6 & 6 \\
\hline $24 \mathrm{hr} p . c$. & 0 & 0 & - \\
\hline $48 \mathrm{hr}$ p.c. & 0 & 0 & 0 \\
\hline $72 \mathrm{hr}$ p.c. & 0 & 0 & 9 \\
\hline $96 \mathrm{hr} p . c$. & 3 & 14 & 1 \\
\hline $120 \mathrm{hr}$ p.c. & 1 & 0 & 1 \\
\hline $144 \mathrm{hr} p . c$. & 0 & 1 & 0 \\
\hline $168 \mathrm{hr}$ p.c. & 0 & 1 & 0 \\
\hline Total & 4 & 16 & 11 \\
\hline $\begin{array}{l}\text { Mean no. of eggs recovered from the } \\
\text { vagina per a pregnant doe }\end{array}$ & 1.3 & 1.3 & 1.1 \\
\hline Mean no. of eggs lost per a pregnant doe & 1.0 & 3.1 & 3.1 \\
\hline
\end{tabular}

appearanec of eggs in the vagina in group $\mathrm{V}$ was 24 hours earlier than that in groups III and IV.

\section{Discussion}

Comparing the present data on egg distribution in the oviduct and uterus of the superovulated rabbits with those of normal rabbits (TSUTSUMI and $\mathrm{HAFEZ}^{26)}$ ), it is suggested that the time required for egg transport through the isthmus is shortened by about 18 hours in superovulated does. However, some eggs of the superovulated does appeared not only in the uterus, but also in the vagina about $40 \mathrm{hr}$ p.c. (Table 3). That is an unexpected phenomenon, because eggs appear commonly in the uterus around $72 \mathrm{hr}$ p.c. ${ }^{26)}$ although EL-BANNA and SACHER ${ }^{12)}$ found that $13 \%$ of eggs located in the vagina of superovulated does $70 \mathrm{hr}$ p.c. As far as the egg distribution pattern in the oviduct and uterus are concerned, no special difference was noted between normally ovulated and superovulated does during the egg transport stage. For example, egg distribution pattern in the uterus of superovulated does $72 \mathrm{hr}$ p.c. was similar to that of normally ovulated does $108 \mathrm{hr}$ p.c. TSUTSUMI and $\mathrm{HAFEZ}^{26)}$ found that some eggs in the proximal uterus were close to the internal os of the cervix in the ovulated does $78 \mathrm{hr}$ p.c., and they assumed that such a rapid transport of eggs occurred immediately after the eggs entered the uterus from the oviduct. Sucha tendency in the egg transport in rabbits could be conjectured from our previous works. ${ }^{15-19)}$ It may be suggested, therefore, that the egg transport through the uterus in rabbit is biphasic; one is a very quick transportof eggs in low percentage which appear very close to the cervix in a short lapse of time after entry to the uterine 
lumen, and the other is a slow transport in most eggs which are distributed in the distal part of the uterine horn and advance gradually to the proximal portion. Some mechanisms involved in the quick transport may be related to the expulsion of the eggs into the vagina.

In recent studies by HODGSON and PAUERSTEIN ${ }^{21)}$, uterine entry of eggs in does treated with hCG alone or hCG followed by artificial insemination occurred between 48 and 60 hours after hCG injection and most eggs had entered the uterus by 72 hours after hCG. In naturally mated rabbits, however, entry of eggs into the uterus did not occur until after $66 \mathrm{hr}$ p.c., and the majority of eggs did not enter the uterus until after $78 \mathrm{hr}$ p.c. Although they carried out flushings of the uterus and vagina, no description was made on the eggs in the vagina. However, when the effect of hCG administration at mating on the egg recovery from the vagina was examined in the present Experiment III, 31 eggs (12.4\% against the total number of corpora lutea) were recovered from 32 does up to $168 \mathrm{hr}$ p.c.

The manipulation for egg recovery from the vagina may affect the egg transport. It was clear, however, that the appearance of eggs in the vagina 24 hours earlier in group $V$ than in group IV was due to an increased dosage of hCG (5 times) and not due to the stimuli by the vaginal washings. SAwYER and MAR$\mathrm{KEE}^{27)}$ described that most attempts to induce ovulation in the estrous rabbit by simple vaginal stimulation have led to negative results, although priming the estrous doe with moderate dosage of estrogen for 2 days, sets the stage for release of pituitary ovulating hormone in response to artificial stimulation of the vagina in $40-45 \%$ of the cases. Therefore, the marked expulsion of eggs into the vagina that occurred from around $40 \mathrm{hr}$ p.c. in super- ovulated does must be due to some actions induced by PMSG priming prior to hCG administration. The acceleration of egg transport and the expulsion of the eggs into the vagina of the superovulated does may be caused by an inbalance between endogenous estrogen and gestagen, resulting from PMSG and/or hCG administration. An abnormal quantity of estrogen and/or gestagen secreted from the ovaries in superovulated does is speculated from the appearance of many unruptured follicles and/ or corpora lutea. ${ }^{28)}$ However, the cause of the fluctuation of the levels of the ovarian hormones in the superovulated rabbit still remain unknown.

Concerning the fertility of eggs, $\mathrm{ADAMS}^{29)}$ described that the mean proportions of eggs fertilized were $98.6 \%$ for ovulated does and $91.6 \%$ for superovulated does, and no significant difference was shown in fertilization rates of eggs between the normally ovulated does and the superovulated does by KENNELLY and FOOTE $^{3)}$, TeSH $^{30)}$ and MAURER et al. ${ }^{31)}$ Other investigators also reported high percentages of eggs fertilized in the superovulated does $^{3,5,7,11,80,31)}$. This shows that fertility of the eggs in the does was not impaired by superovulation treatment. In the experiment by Fujimoto et al., ${ }^{23)} 74.9 \%$ of eggs in the superovulated does and $86.9 \%$ in the ovulated does were observed as blastocyst, when the uterine horns were flushed on the 5th to 7 th day of pregnancy. In Experiments I and II, however, $48.8 \%$ of the eggs recovered from the vagina were in cleavage (Table 5). Such the low fertility of the superovulated eggs may be due to using bucks in unsatisfactory condition, because these experiments were carried out during the hot summer season.

TAKEISHI et al. ${ }^{32)}$ claimed that uterine entry of the unfertilized eggs which were ovulated 
Table 5. Classification of eggs recovered from the vagina of superovulated does

\begin{tabular}{|c|c|c|c|}
\hline $\begin{array}{l}\text { Time of egg } \\
\text { recovery } \\
\text { (hr p.c.) }\end{array}$ & $\begin{array}{l}\text { Classification of } \\
\text { egg recovered }\end{array}$ & $\begin{array}{l}\text { No. of eggs } \\
\text { recovered }\end{array}$ & Total (\%) \\
\hline \multicolumn{4}{|c|}{ Fertilized eggs } \\
\hline $48-51$ & $2-8$ cell stage & 53 & \\
\hline $48-72$ & 16 cell stage & 22 & \\
\hline $45-78$ & 32 cell stage & 29 & \\
\hline $54-96$ & Morula stage & 99 & \\
\hline $78-96$ & Blastocyst stage & 16 & 219 (38.3) \\
\hline \multicolumn{4}{|c|}{ Degenerated fertilized eggs } \\
\hline $45-168$ & 2-32 cell stage & 26 & \\
\hline $60-96$ & Morula stage & 20 & \\
\hline 78-192 & Blastocyst stage & 14 & $60(10.5)$ \\
\hline 24-192 & Degenerated and/or unfertilized eggs & 293 & $293(51.2)$ \\
\hline $144-192$ & \multicolumn{3}{|c|}{ Empty zona pellucida $\quad$ Several } \\
\hline
\end{tabular}

* Eggs recovered in Experiments I and II were combined.

by hCG administration occurred 10 hours earlier than that of the fertilized eggs in the does mated naturally. Although IsHIJIMA et $a l .^{9)}$ and TsunODA et al. ${ }^{11)}$ supported this statement, the present study could not confirm such a phenomenon in vaginal entry of eggs. Our results were in agreement with the statement by HodgSON and PAUERstein, ${ }^{21)}$ that fertilized and unfertilized eggs travelled at the same rate in the reproductive tracts of rabbits.

Acknowledgment. The authors are grateful to the Teikoku-zōki Co., Ltd., Japan, for supplying PMSG. This work was supported in part by a Grantin-Aid for Scientific Research Project (Project no. 348063) from the Ministry of Education, Science and Culture, Japan.

\section{References}

1) Takeuchi, S., H. Shimizu, Y. Sakuma \& M. Sato: Japan. J. Anim. Reprod. 6, 4, 1960.

2) HAFEZ, E.S. E.: J. Morph. 108, 327, 1961.

3) Kennelly, J. J. \& R. H. Foote: J. Reprod. Fert. 9, 177, 1965.

4) IshiJima, Y., M. Iтo \& Y. Azuma: Japan. $J$. Anim. Reprod. 15, 29, 1969.

5) SAKuma, Y., Y. IshiJima \& M. ONo: Bull. Coll. Agr. \& Vet. Med., Nihon Univ. (18), 25, 1964.
6) IshiJima, Y. \& Y. SAkuma: Japan. J. Anim. Reprod. 12, 133, 1967.

7) Ishijima, Y., M. Ito, T. Hirabayashi \& Y. SakUMa: Japan. J. Anim. Reprod. 14, 43, 1968.

8) ADAMs, C. E.: J. Endocrinol. 24, 471, 1962.

9) IshiJima, Y., M. Ito, T. Hirabayashi \& $Y$. SAKUMA: Japan. J. Anim. Reprod. 13, 71, 1967.

10) IshiJima, Y.: Japan. J. Anim. Reprod. 19, 43, 1973.

11) Tsunoda, Y., A. Iritani \& Y. Nishikawa: Japan. J. Zootech. Sci. 49, 89, 1978.

12) El-Banna, A. A. \& B. Sacher: J. Endocrinol. 68, 331, 1976.

13) Adams, C.E.: In Preimplantation Stages of Pregnancy (G.E.W. Wolstenholme \& M. O'Connor, eds.) p. 345, J. \& A. Churchil, London, 1965.

14) Tsutsumi, Y. \& T. TAkedA: Japan. J. Zootech. Sci. 47, 509, 1976.

15) Tsutsumi, Y., T. Takeda, K. Yamamoto \& $Y$. TANABE: J. Reprod. Fert. 48, 393, 1976.

16) Takeda, T., K. Yamamoto, Y. Tanabe \& Y. Tsutsumi: Memoirs Facul. Agr., Hokkaido Univ. 10, 231, 1977.

17) Takeda, T., Y. Tsutsumi, Y. Tanabe \& $\mathrm{K}$. Yамамото: Fertil. Steril. 28, 759, 1977.

18) Takeda, T., Y. Tsutsumi, S. HaRA \& M. IdA: Fertil. Steril. 30, 79, 1978.

19) Takeda, T., H. Suzuki, S. Matsui, Y. Terami \& Y. Tsutsumi: Japan. J. Anim. Reprod. 24, $184,1978$.

20) Tsutsumi, Y., T. TAkeda, M. IdA \& S. Hara: J. Facul. Agr., Hokkaido Univ. 58, 557, 1978. 
21) Hodgson, B. \& C. J. Pauerstein: Biol. Reprod. 14, 377, 1976.

22) Hafez, E. S. E. \& S. Sugatara: J. Morph. 124. 133, 1968.

23) Fujimoto, S., N. Pahlavan \& W. R. Dukelow: J. Reprod. Fert. 40, 177, 1974.

24) Howe, G. R.: J. Reprod. Fert. 21, 339, 1970.

25) ORSINI, M. W.: J. Reprod. Fert. 3, 283, 1962.

26) Tsutsumi, Y. \& E.S. E. HAFEz: J. Morph. 144, 323, 1974.

27) SAWYer, C. H. \& J. E. MARKeE: Endocrinolo- gy 65, 614, 1959.

28) IshiJima, Y. \& K. IshidA: Japan. J. Fertil. Steril. 15, 194, 1970.

29) Adams, C. E.: J. Reprod. Fert. 1, 315, 1960.

30) TeSH, J. M.: J. Endocrinol. 35, xxviii, 1966.

31) Maurer, R. R., W.L. Hunt \& R.H. Foote: J. Reprod. Fert. 15, 93, 1968.

32) TaKeishi, M., T. OUChI, K. Ichihara, T. TsuNEKANE \& A. Sugawa: Bull. Coll. Agr. \& Vet. Med., Nihon Univ. (16), 28, 1963.

(Received June 6, 1979)

\section{過排卵処理家鬼の胵からの採卵及び生殖器道内卵の分布}

堤 義雄・寺見 裕・武田哲男・鈴木裕之・松井 滋

(北海道大学農学部 畜産学科)

過排卵処理家鬼の卵管内卵移動は促進され，子宮内卵 回収数は交配後の時間とともに急速に減少することや， 交配後 72 82 時間で 12 13\% の卵が腔内に排出され ていることが報告されている。他方 estrogen, gestagen や $\mathrm{PGF}_{2 \alpha}$ で処理した家鬼の胵内から相当数の卵が 採取され，それらの一部は生存性を持つものであること が証明された。そこで本研究では, 過排卵処理家鬼の胵 内から採卵を試みるとともに，卵管と子宮内卵の分布状 悲を调べた。また，hCG 投与が卵の卵管内通過を早め るとの報告 ${ }^{21)}$ あるので， hCG 処理による胵からの採 卵飞検待した。胵からの採卵方法は前報 ${ }^{18)}$ と同様であ $\eta$, 卵分布状態は卵管と子宮の透明棒本 ${ }^{24,25)}$ により調へ た。過排卵は，PMSG 200 IU を筋注後 80 時間目に交 配し，同時に hCG $100 \mathrm{IU}$ を静注して誘起した。

実験 I (斐 1，2）では交配後 18，24，36，48，60，72， 84,96 時間目に屠殺し, 生殖器の 透明標本を作製した が, 居殺前に 0 8 回の腔洗浄を行い, 胵からの採卵も 試みた。その結果, 交配後 48 時間目から卵は採取され 始め, 96 時間目までに黄体数に対して $43 \%$ の卵が腔か ら回収された。卵管と子宮内卵の分布状態（図 1）飞は
過排卵処理による特異性はみられなかったが，通常の交 配家鬼に比較して，卵管内卵通過が敊よそ 18 時間ほど 早まっているようであった。

実験II（表 3 )では実験 I の結果を確かめるとともに， 胵からの採卵状態を調べた。グループIでは主に 6 時間 間隔で腔洗浄を行ったが，交配後 24 時間で少数の卵が 採取されたので，グループIでは間隔を短縮して洗浄し た。その結果，卵回収率 $44.2 \%, 1$ 羽当たり採卵数 36.6 個となり，特に交配後 2 日日から 4 日目に集中して採取 された。

実駼而（表4）では交配のみの群，交配特に $20 \mathrm{IU}$ また は $100 \mathrm{IU}$ の hCG を静注した碓の 3 群で腔洗浄を陚 み,ごく少数であったが前 2 者の群で交配後 96 時閌目， 後者からは 72 時間目で採畉され，问笚位投与で 1 日早 く卵が採取された。

以上の結果から，過排卵処理家鬼の腔に多数の卵が早 い時期に出現したのは，PMSG の前処理の影響が強い ものと考兄られた。なお，過排卵処理家鬼の腟から採取 された卵を 1 羽の偽妊娠家鬼に移植した結果， 4 羽の正 常産子が得られた。 